\title{
Influence of microphytobenthos on the nutrient flux between sediment and water: a laboratory study
}

\author{
Kristina Sundbäck ${ }^{1}$, Wilhelm Granéli ${ }^{2}$ \\ ${ }^{1}$ Department of Marine Botany, University oí Göteborg, Carl Skottsbergs Gata 22, S-413 19 Göteborg, Sweden \\ ${ }^{2}$ Department of Limnology, University of Lund, PO Box 65, S-221 00 Lund, Sweden
}

\begin{abstract}
The importance of microphytobenthos as a regulator of the flux of inorganic phosphorus and nitrogen between sediment and water was investigated in a laboratory study. Sediment from the SE Kattegat was incubated in nutrient-enriched seawater during exposure to varying light quantities $(0,5$, 10 , and $\left.30 \mu \mathrm{E} \mathrm{m}^{-2} \mathrm{~s}^{-1}\right)$. Microphytobenthos growth was limited by both inorganic nutrients and light quantity. When exposed to no-light conditions, chlorophyll a content of the sediment decreased only slightly and remained at an almost constant level $\left(50\right.$ to $\left.55 \mathrm{mg} \mathrm{m}^{-2}\right)$ for several weeks, and increased rapidly when exposed to light. A relationship was observed between light quantity and the rate and direction of the flux of $\mathrm{NH}_{4}^{+}$and $\mathrm{PO}_{4}^{3-}$, but not $\mathrm{NO}_{3}^{-}$, between the sediment and overlying water The indirect influence of the microphytobenthos on the nutrient flux, i.e. by changes in the oxygen concentration, seemed more important than the direct effect by uptake by the algae. The rate of release of phosphate from the sediment exposed to darkness was up to $0.2 \mathrm{mmol} \mathrm{PO}_{4} \mathrm{~m}^{-2} \mathrm{~d}^{-1}$ The maximum mean rate of ammonia release was $1.6 \mathrm{mmol} \mathrm{m} \mathrm{m}^{-2} \mathrm{~d}^{-1}$ in the dark and ca $0.1 \mathrm{mmol} \mathrm{m} \mathrm{m}^{-2} \mathrm{~d}^{-1}$ at $5 \mu \mathrm{E}$ $\mathrm{m}^{-2} \mathrm{~s}^{-1}$. When the amount of light was $\geqslant 10 \mu \mathrm{E} \mathrm{m} \mathrm{m}^{-2} \mathrm{~s}^{-1}$, the microbenthic activity (oxygen production and increased nutrient requirements) prevented the release of $\mathrm{PO}_{4}$ and $\mathrm{NH}_{4}$ from the sediment.
\end{abstract}

\section{INTRODUCTION}

The role in coastal ecosystems of sublittoral microphytobenthos at depths greater than a few metres has rarely been discussed, probably because the benthic microflora has been considered to play a subordinate role in primary production compared with the phytoplankton. However, considerable primary production and biomass of sediment-associated microflora have been documented for depths greater than $10 \mathrm{~m}$ in both marine (Boucher 1977, Chassé 1983, Plante-Cuny 1984, Sundbäck 1986) and lacustrine temperate waters (Romagoux 1976, Björk-Ramberg 1984).

In coastal areas regeneration of nutrients from the sediment is important for primary production in the water column (Rowe et al. 1975, Blackburn \& Henriksen 1983, Flint \& Kamykowski 1984, de Vries \& Hopstaken 1984). In shallow water, the sediment-associated microflora may compete for nutrients and thereby function as a 'filter' (Blackburn \& Henriksen 1979, Hansson in press) influencing the inorganic nutrient flux between sediment and water (Henriksen et al. 1980,
Blackburn \& Henriksen 1983, Kelderman 1984, Granéli \& Sundbäck 1985, Asmus 1986). The microphytobenthos also affects the oxygen conditions at the sedimentwater interface (Revsbech \& Jörgensen 1983, Baille 1986, Granéli \& Sundbäck 1986) and this may, in turn, influence nitrogen turnover processes at the sediment surface (Andersen et al. 1984, Enoksson 1987) and desorption rates for $\mathrm{PO}_{4}$ (e.g. Balzer et al. 1983).

To study the relationship between microphytobenthos and the inorganic nutrients in the bottom water, we designed an experiment in which sediment was exposed to a series of light quantities. As oxygen concentration may influence the nutrient fluxes, the $\mathrm{O}_{2}$ levels in the overlying water were also measured (see Granéli \& Sundbäck 1986).

\section{MATERIAL AND METHODS}

Experiments were conducted in aquaria containing natural sand sediment, collected on 28 October 1984 from grab samples (ca $10 \mathrm{~cm}$ deep) from a depth of $15 \mathrm{~m}$ 
in Laholm Bay, Sweden (56 $33^{\prime} \mathrm{N}, 12^{\circ} 50^{\prime} \mathrm{E}$ ) (in the SE Kattegat). Samples were divided into 2 layers (the top $1 \mathrm{~cm}$ was scraped away and kept separate). The sediment was sieved (mesh size $0.55 \mathrm{~mm}$ ) to remove macrofauna and homogenized to minimize initial variability within and among experimental units caused by patchiness of the microflora and meio- and microfauna.

Because sampling was carried out late in the season when algae were not in abundance at $15 \mathrm{~m}$, surficial sediment (top $1 \mathrm{~cm}$ ) was collected on 30 October from the shallow $(0.5 \mathrm{~m})$ Salviken Bay in Öresund. This algae-rich sediment was sieved and mixed with the surficial sediment from Laholm Bay (proportions ca $3: 1$ ). The species constituting the microflora in the 2 sediments were not essentially different.

A sample of the lower layer of the Laholm Bay sediment was spread to a depth of $2 \mathrm{~cm}$ over the base of cylindrical dark-grey 6 I PVC aquaria $\left(346 \mathrm{~cm}^{2}\right)$. A $2 \mathrm{~cm}$ layer of the mixed surficial sediment was spread over the lower layer. Aquaria were completely filled with filtered (Whatman GF/F, retention $0.7 \mu \mathrm{m}$ ) water collected from a depth of $15 \mathrm{~m}$ in Laholm Bay (salinity $21 \%$ ), and then covered with PVC (dark aquaria) or glass lids of varying light transparencies (white paper was used as neutral filter). The joints between the aquaria and their lids were sealed with silicon grease to minimize exchange of oxygen with the atmosphere,

The experimental arrangement consisted of 10 aquaria $(5 \times 2$ replicates $)$ held at $14.5 \pm 1^{\circ} \mathrm{C}$ and the experiment was run for $81 \mathrm{~d}$ ( 9 Nov to $24 \mathrm{Jan}$ ) with a $16 / 8$ h light/dark cycle. Duplicate aquaria were randomly chosen and exposed to 4 different light regimes $\left(0,5,10\right.$ and $30 \mu \mathrm{E} \mathrm{m} \mathrm{m}^{-2} \mathrm{~s}^{-1}$, equivalent to 0 to $1.7 \mathrm{E}$ $\left.\mathrm{m}^{-2} \mathrm{~d}^{-1}\right)$, a range that is similar to the range observed in the field at approximately $15 \mathrm{~m}$ (Sundbäck 1986). After $36 \mathrm{~d}$, the light treatments were inverted $10 \mu \mathrm{E}$ to $30 \mu \mathrm{E}$ and vice versa; $5 \mu \mathrm{E}$ to $10 \mu \mathrm{E}$ and vice versa) to check that the differences between the aquaria were mainly a result of different light regimes and to determine how rapidly the microcosms reacted to changed light conditions.

At the beginning of the experiment, nutrients 1700 $\mu M N$ as $\mathrm{NaNO}_{3}$ and $8.9 \mu M \mathrm{P}$ as $\mathrm{K}_{2} \mathrm{HPO}_{4}$ ) were added to the water in all but 2 of the aquaria initially exposed to $30 \mu \mathrm{E} \mathrm{m}^{-2} \mathrm{~s}^{-1}$. The amount of phosphate added was within the same order of magnitude as $\mathrm{PO}_{4}$ concentrations normally encountered in the pore water, while an excess of nitrate was added to prevent nutrient limitation. The growth of benthic algae and phytoplankton in Laholm Bay is not limited by phosphate (Nyman \& Granéli 1983).

Initially, the aquaria were sampled each week, and subsequently (towards the end of the experiment), samples were taken each fortnight. Samples were always taken 3 to $4 \mathrm{~h}$ after the beginning of the light period. For each sampling, $350 \mathrm{ml}$ aliquots of the overlying water were collected for analyses from each aquarium and the volume replaced by filtered seawater. The following measurements were performed on these aliquots: inorganic nitrogen $\left(\mathrm{NO}_{3}^{-}+\mathrm{NO}_{2}^{-}\right.$, $\mathrm{NH}_{4}^{+}$), inorganic phosphorus $\left(\mathrm{PO}_{4}^{3-}\right)$ and $\mathrm{O}_{2}$ and ${ }^{14} \mathrm{C}$ assimilation (to check for phytoplankton growth). Nutrients were analysed according to methods described in Carlberg (1972), oxygen levels were determined using the Winkler technique and ${ }^{14} \mathrm{C}$ assimilation was measured according to Aertebjerg Nielsen \& Bresta (1984).

The response of the microphytobenthos was monitored by both the change in the chlorophyll a content and the ${ }^{14} \mathrm{C}$-assimilation of samples taken from the top $3 \mathrm{~mm}$ of the sediment with a cut-off plastic syringe $\left(0.64 \mathrm{~cm}^{2}\right)$. Six samples from each aquarium were pooled. Chlorophyll a was extracted for $24 \mathrm{~h}$ with $90 \%$ acetone and measured according to Lorenzen (1967). The ${ }^{14} \mathrm{C}$-assimilation was measured by incubating subsamples from the pooled sediment sample in glass flasks containing $25 \mathrm{ml}$ filtered water from the aquaria. All samples were incubated for $2 \mathrm{~h}$ under the same conditions as the experimental system.

A semi-quantitative estimate of microfloral succession was obtained by microscopically examining fresh sediment samples.

\section{RESULTS}

The replicate aquaria for each treatment yielded comparable data and the deviation of the measured values was generally less than $10 \%$ (Figs. 1 to 6).

For the first $36 \mathrm{~d}$, the chlorophyll a content decreased only slightly from initial values (ca $70 \mathrm{mg} \mathrm{m}^{-2}$ ) in aquaria exposed to no light, remained stable at $5 \mu \mathrm{E}$ $\mathrm{m}^{-2} \mathrm{~s}^{-1}$ light quantity, increased for the first $2 \mathrm{wk}$ in aquaria exposed to $10 \mu \mathrm{E}$ and increased up to $100 \mathrm{mg}$ $\mathrm{m}^{-2}$ within $2 \mathrm{wk}$ in aquaria exposed to $30 \mu \mathrm{E} \mathrm{m} \mathrm{m}^{-2} \mathrm{~s}^{-1}$ (Fig. 1). In the aquaria without added nutrients the values decreased slightly after an initial rise.

The ${ }^{14} \mathrm{C}$-assimilation of the sediment exposed to no light was $<1$ to $3 \mathrm{mg} \mathrm{C} \mathrm{m}{ }^{-2} \mathrm{~h}^{-1}$ (Fig. 2). The primary production at 5 and $10 \mu \mathrm{E}$ varied between 5 and $10 \mathrm{mg}$ $\mathrm{C} \mathrm{m}^{-2} \mathrm{~h}^{-1}$ and between 12 and $19 \mathrm{mg} \mathrm{C} \mathrm{m}^{-2} \mathrm{~h}^{-1}$, respectively (Fig. 2). At $30 \mu \mathrm{E}$ the production rate increased to between 90 and $100 \mathrm{mg} \mathrm{C} \mathrm{m}^{-2} \mathrm{~h}^{-1}$ within $4 \mathrm{wk}$ (Fig. 2). In the aquaria exposed to $30 \mu \mathrm{E} \mathrm{m}^{-2} \mathrm{~s}^{-1}$ without added nutrients the values decreased slowly (Fig. 2). The ${ }^{14} \mathrm{C}$-assimilation of the overlying water was low $\left(<1 \mathrm{mg} \mathrm{m}^{-2} \mathrm{~h}^{-1}\right.$ ) and, consequently, interference by phytoplankton production during the experiment could be ignored.

After $36 \mathrm{~d}$, when the light quantity was changed from 


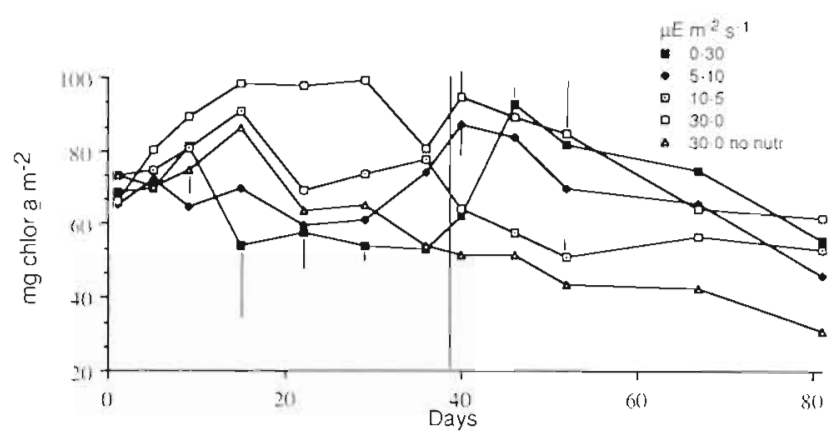

Fig. 1 Chlorophyll a content of the sediment in aquaria exposed to 4 different light regimes. Vertical line denotes inversion of light treatments ( 0 to 30,5 to $10 \mu \mathrm{E} \mathrm{m} \mathrm{m}^{-2} \mathrm{~s}^{-1}$ etc.). Range of values of duplicate aquaria appear only above or below mean values and are shown only when the deviation from the mean was greater than $10 \%$

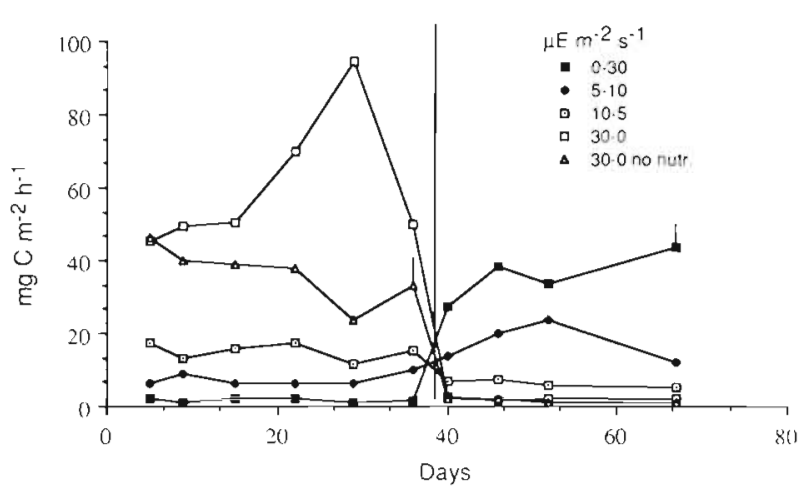

Fig. $2 .{ }^{14} \mathrm{C}$-assimilation of the sediment in aquaria exposed to 4 different light regimes. For further explanation see Fig. 1

0 to 30 and from 5 to $10 \mu \mathrm{E} \mathrm{m}^{-2} \mathrm{~s}^{-1}$, both chlorophyll $a$ content and ${ }^{14} \mathrm{C}$-assimilation of the sediment initially increased (Figs. 1 and 2). There was no marked decrease in chlorophyll a content when the light was

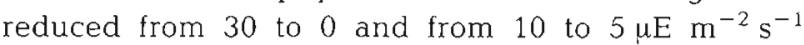
(Fig. 1).

The change in the $\mathrm{O}_{2}$-concentration of the overlying water was correlated with light quantity (Fig. 3). Although the peaks of the curves did not always coincide, the values exhibit a similar trend to those obtained for chlorophyll a content and primary production of the sediment. The change from 30 to $0 \mu \mathrm{E}$ $\mathrm{m}^{-2} \mathrm{~s}^{-1}$ induced the oxygen concentration in the nutrient-enriched aquaria to fall to zero within $1 \mathrm{wk}$, and after an additional $20 \mathrm{~d}$, a smell of $\mathrm{H}_{2} \mathrm{~S}$ appeared. In the aquaria without added nutrients, the values decreased more slowly and stabilized at $2 \mathrm{ml} \mathrm{O}_{2} \mathrm{l}^{-1}$. Additional data regarding oxygen concentrations are presented in Granéli \& Sundbäck (1986).

During the first $5 \mathrm{~d}$, the concentration of $\mathrm{PO}_{4}$ decreased rapidly in all aquaria with added nutrients (maximum rate was ca $250 \mu \mathrm{mol} \mathrm{m} \mathrm{m}^{-2} \mathrm{~d}^{-1}$ at $30 \mu \mathrm{E}$ ) (Fig. 4). After an additional $1 \mathrm{wk}$ the uptake rate decreased with decreased light exposure $\left(70 \mu \mathrm{mol} \mathrm{m} \mathrm{m}^{-2} \mathrm{~d}^{-1}\right.$ at

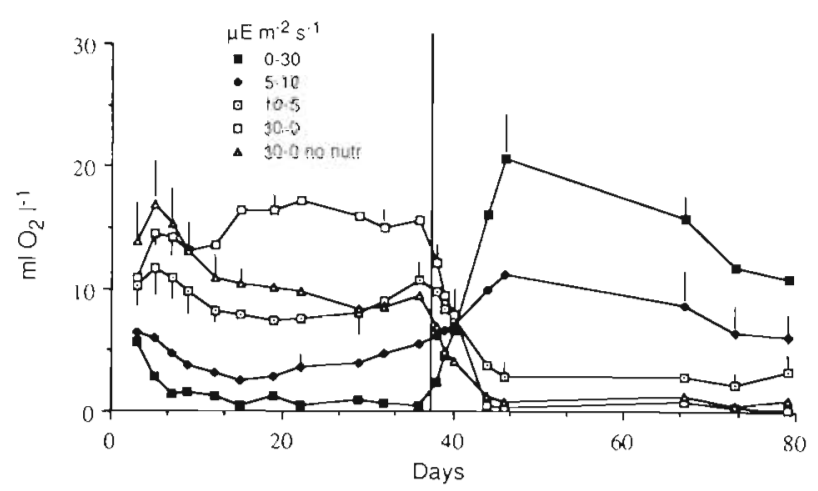

Fig. 3. Oxygen concentration of the overlying water in aquaria exposed to 4 different light regimes. For further explanation see Fig. 1

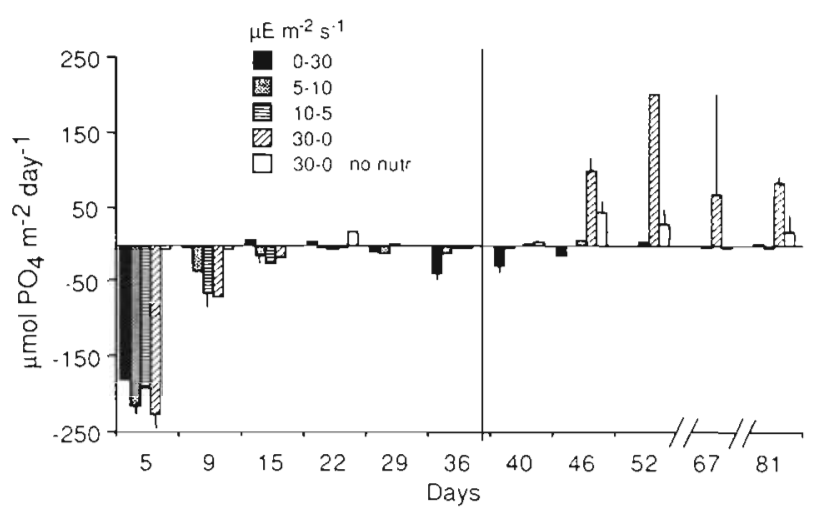

Fig. 4. Rates of decrease and increase of $\mathrm{PO}_{4}^{3-}$ in the overlying water in aquaria exposed to 4 different light regimes. Ranges of values appear only above the mean values. For further explanation see Fig. 1

$30 \mu \mathrm{E}$ and $35 \mu \mathrm{mol} \mathrm{m}^{-2} \mathrm{~d}^{-1}$ at $5 \mu \mathrm{E}$ ). In the dark aquaria, the concentration of $\mathrm{P}$ remained almost unchanged (ca $0.5 \mathrm{mmol} \mathrm{m}^{-2}$ ) from Day 5 to 29 .

Changing the light quantity from 30 to $0 \mu \mathrm{E} \mathrm{m}^{-2} \mathrm{~s}^{-1}$ induced a marked flux of $\mathrm{PO}_{4}$ out of the sediment in aquaria containing added nutrients as the $\mathrm{O}_{2}$ concentration decreased (the maximum rate of increase was $200 \mu \mathrm{mol} \mathrm{m}{ }^{-2} \mathrm{~d}^{-1}$ ) (Fig. 4). The concentrations of $\mathrm{PO}_{4}$ also increased in the aquaria without added nutrients (maximum rate of increase was approximately $80 \mu \mathrm{mol}$ $\left.\mathrm{m}^{-2} \mathrm{~d}^{-1}\right)$. Conversely, only a slight increase in $\mathrm{P}$ was noted in the aquaria initially kept in the dark (6 to $8 \mu \mathrm{mol} \mathrm{m} \mathrm{m}^{-2} \mathrm{~d}^{-1}$ during Weeks 2 and 3) (Fig. 4).

The $\mathrm{NH}_{4}$ concentration in the overlying water was initially low (150 to $250 \mu \mathrm{mol} \mathrm{m} \mathrm{m}^{-2}$ ) in all aquaria ( $\mathrm{N}$ was added as $\left.\mathrm{NO}_{3}\right)$. Concentrations increased in the aquaria that were kept in the dark and at $5 \mu \mathrm{E} \mathrm{m} \mathrm{m}^{-2} \mathrm{~s}^{-1}$ for the first $36 \mathrm{~d}$. In the aquaria kept in the dark the $\mathrm{NH}_{4}$ concentration increased about 100 times, i.e. to between 15 and $20 \mathrm{mmol} \mathrm{m}{ }^{-2}$ (which is equivalent to a mean rate of 0.6 to $0.7 \mathrm{mmol} \mathrm{m} \mathrm{m}^{-2} \mathrm{~d}^{-1}$ ) (Fig. 5). Inverting light treatments changed the direction of the $\mathrm{NH}_{4}$ flux 


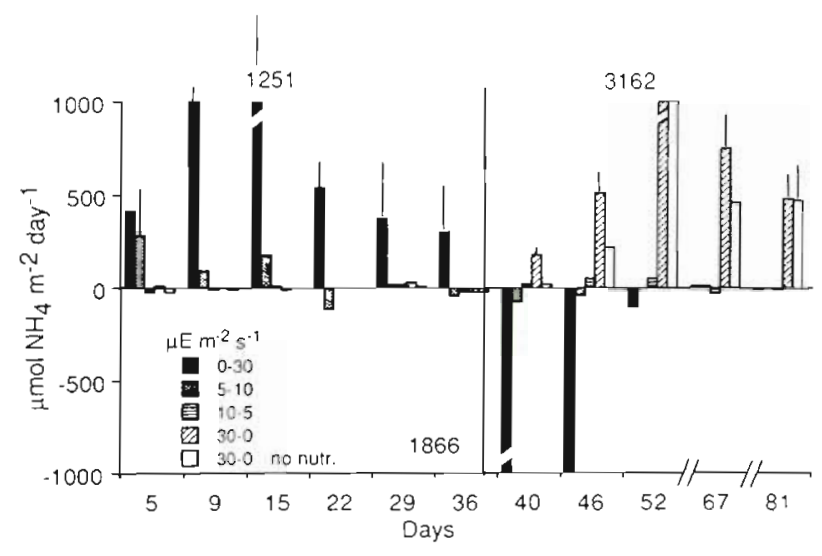

Fig. 5. Rates of decrease and increase of $\mathrm{NH}_{4}^{+}$in the overlying water in aquaria exposed to 4 different light regimes. For further explanation see Figs. 1 and 4

(Fig. 5). After switching from 0 to $30 \mu \mathrm{E} \mathrm{m}^{-2} \mathrm{~s}^{-1}$ the $\mathrm{NH}_{4}$ concentrations decreased rapidly (mean rate $1.5 \mathrm{mmol}$ $\left.\mathrm{m}^{-2} \mathrm{~d}^{-1}\right)$. Altering the light regime from 30 to $0 \mu \mathrm{E}$ $\mathrm{m}^{-2} \mathrm{~s}^{-1}$ increased the $\mathrm{NH}_{4}$ levels at a mean rate of 1.6 $\mathrm{mmol} \mathrm{m} \mathrm{m}^{-2} \mathrm{~d}^{-1}$. The increase was less in the control aquaria (approximately $0.5 \mathrm{mmol} \mathrm{m} \mathrm{m}^{-2} \mathrm{~d}^{-1}$ ) (Fig. 5). The mean release of $\mathrm{NH}_{4}$ at $5 \mu \mathrm{E} \mathrm{m}^{-2} \mathrm{~s}^{-1}$ was 0.1 (range 0.02 to 0.28$) \mathrm{mmol} \mathrm{m}^{-2} \mathrm{~d}^{-1}$.

The concentration of $\mathrm{NO}_{3}+\mathrm{NO}_{2}$ varied less than the amounts of $\mathrm{PO}_{4}$ and $\mathrm{NH}_{4}$ at the different light levels (Fig. 6). The uptake rate was highest during the first

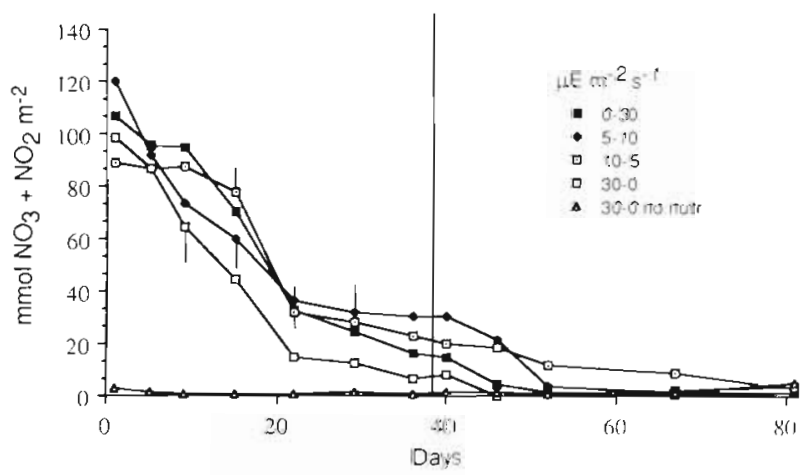

Fig. 6. Concentrations of $\mathrm{NO}_{3}^{-}+\mathrm{NO}_{2}^{-}$in the overlying water in aquaria exposed to 4 different light regimes. For further explanation see Figs. 1 and 4

$3 \mathrm{wk}$ and varied between 1.8 and $5 \mathrm{mmol} \mathrm{m} \mathrm{m}^{-2} \mathrm{~d}^{-1}$. No increase in nitrate concentration was observed during the experiment.

Initially the benthic microflora was dominated by diatoms (mainly epipsammic forms e.g. Opephora olsenii Möller and small Navicula species). This dominance of diatoms persisted throughout in the aquaria without added nutrients, but motile diatoms became more abundant during the experiment. Towards the end of the period of light exposure, however, a dinoflagellate (Amphidinium sp.) became abundant. In the nutrient-enriched aquaria kept at a light quantity of $30 \mu \mathrm{E} \mathrm{m}^{-2} \mathrm{~s}^{-1}$, a thick carpet of filamentous cyanobacteria (Spirulina of. subsalsa and Lyngbya spp.) developed. Removal of the light resulted in disappearance of the cyanobacteria while a vital diatom flora remained, even after the presence of $\mathrm{H}_{2} \mathrm{~S}$ was noted. When the dark aquaria were exposed to $30 \mu \mathrm{E}$ light after $36 \mathrm{~d}$, a thick dark brown carpet of motile diatoms (mainly Amphora spp.) rapidly developed.

\section{DISCUSSION}

The chlorophyll $a$ and ${ }^{14} \mathrm{C}$-uptake curves indicated that light was a limiting factor during the experiment. The light saturation range for microflora from $15 \mathrm{~m}$ depth in Laholm Bay is 50 to $100 \mu \mathrm{E} \mathrm{m}^{-2} \mathrm{~s}^{-1}$ (Sundbäck 1986). Admiraal et al. (1984) found that intertidal diatom species were able to grow in the range 0.2 to $40 \mathrm{E} \mathrm{m}^{-2} \mathrm{~d}^{-1}$. In our experiment, $0.6 \mathrm{E} \mathrm{m}^{-2} \mathrm{~d}^{-1}(10 \mu \mathrm{E}$ $\mathrm{m}^{-2} \mathrm{~s}^{-1} \times 16 \mathrm{~h}$ ) was sufficient to support an autotrophically dominated system $(\mathrm{P} / \mathrm{R}>1$; see also Granéli \& Sundbäck 1986). This level of irradiance is reached at $15 \mathrm{~m}$ between May and August $\left(0.7\right.$ to $\left.1 \mathrm{E} \mathrm{m}^{-2} \mathrm{~d}^{-1}\right)$. In Laholm Bay considerable microphytobenthic production takes place even as deep as 15 to $16 \mathrm{~m}$ (Sundbäck 1986).

In the dark, chlorophyll a content of the sediment remained at a constant level for weeks. Subsequent exposure to light induced a rapid initiation of photosynthesis. Despite slightly increasing values of ${ }^{14} \mathrm{C}$-uptake, the decrease in chlorophyll a values towards the end of the experiment (Fig, 1) most probably reflects an adaptation of the algae to increased light levels by decreased chlorophyll content of the cells. Functional chlorophyll a is usually found in the sediment at least down to a depth of $10 \mathrm{~cm}$ (e.g. Cadée \& Hegeman 1974 . Gargas \& Gargas 1982). Gargas \& Gargas (1982) found no change in the photosynthetic capacity of microphytobenthos kept in the dark for 4 mo and Admiraal et al. (1984) found that benthic diatom species survived more than $40 \mathrm{~d}$ in dark on sterilized sand and that during light limitation a mixed type of growth (photoheterotrophic) occurs. For diatoms capable of heterotrophic growth, Hellebust \& Lewin (1977) demonstrated chlorophyll a synthesis in the absence of light.

Changes in the species composition of the benthic microflora with nutrient enrichment have been observed (e.g. van Raalte et al. 1976, Pringle \& Bowers 1984). Kennett \& Hargraves (1985) observed that seasonal anoxia affected the species composition of the benthic diatoms and that some species appeared to be adapted to the presence of sulfide ions. 
The microphytobenthos influences the nutrient flux both directly through nutrient uptake from water and sediment, and indirectly by affecting the oxygen concentration at the sediment-water interface by photosynthesis and respiration. The latter effect seemed to be more important in our experiment. Microbial nitrogen transformation as well as phosphate adsorption and precipitation are redox sensitive. The uptake of nutrients by the sediment is also affected by bioturbation (e.g. Kristensen \& Blackburn 1987). Although bioturbation (and grazing) by the macrofauna (but not meio- and microfauna) was initially suppressed by sieving the sediment, bioturbation may have occurred later during the experiment.

Decreasing values for both primary production and chlorophyll a content in aquaria without nutrient addition demonstrate that the microflora was nutrient limited (Figs. 1 and 2). Although the interstitial water often contains concentrations of inorganic nutrients orders of magnitude higher than the overlying water, the marine microphytobenthos appear to be nutrient limited (mainly by N) and hence compete for nutrients in the overlying water (Henriksen et al. 1980, Connor et al. 1982, Blackburn \& Henriksen 1983, Wonnerberger \& Höpner 1984, de Vries \& Hopstaken 1984, Granéli \& Sundbäck 1985, Asmus 1986, Sundbäck 1986). In the Dutch Wadden Sea the microbenthic primary production has increased concomitant with the increase in nutrient loading (Cadée 1984).

The rapid initial uptake of added $P$ was approximately the same for all aquaria (even those not exposed to light) and may be due to adsorption to sediment particles during oxic conditions (Watanabe \& Tsugonai 1984). By comparing the decrease of P-concentration of the overlying water in the dark and the light in our experiment, and assuming that non-biological Padsorption equals the decrease in the dark from Day 1 to Day 5, adsorption would account for approximately $60 \%$ of the sediment uptake in the light during the first week.

Provided the light level facilitated adequate oxygen production, no $\mathrm{P}$ was released from the sediment. The fact that P-release in the dark was more rapid after an initial $5 \mathrm{wk}$ period of light exposure, than without an initial light period, suggests that the increased production of organic material by the algae, combined with increased respiration, enhances the P-release. The maximum rate at which $P$ was released during anoxic conditions (200 umol $\mathrm{P} \mathrm{m}^{-2} \mathrm{~d}^{-1}$ ) was the same as previously found for a N-rich bay in SW Sweden (Granéli \& Sundbäck 1985). Granéli (1984) measured phosphate release rates during anoxic conditions between 60 and $150 \mu \mathrm{mol} \mathrm{P} \mathrm{m} \mathrm{m}^{-2} \mathrm{~d}^{-1}$ for silty sediments from a depth of $20 \mathrm{~m}$ in the outer part of Laholm Bay, but during oxic conditions, no phosphate was released. Blackburn \&
Henriksen (1983) found rates of approximately $50 \mu \mathrm{mol}$ $\mathrm{P} \mathrm{m}^{-2} \mathrm{~d}^{-1}$ for sediment taken from a depth of 14 to $25 \mathrm{~m}$ in the Kattegat. These rates lie well within the range measured for aquaria without added nutrients in the work presented here (max. $80 \mu \mathrm{mol} \mathrm{P} \mathrm{m}{ }^{-2} \mathrm{~d}^{-1}$ ).

While nitrate fluxes are often directed towards the sediment because of denitrification, at least when there are high nitrate concentrations in bottom-near waters (as in our experiment), there is usually a net outflow of ammonia from sediments (Florek \& Rowe 1983, Boynton \& Kemp 1985, Nowicki \& Nixon 1985).

We found an inverse relation between the amount of light and the release of $\mathrm{NH}_{4}$ from the sediment. Henriksen et al. (1980) found a marked difference in ammonium flux for light (day) and dark (night) conditions, indicating that the microflora prevents ammonium from leaving the sediment surface during daytime (cf. Kelderman 1984). Our values for ammonia release in the dark $10.5 \mathrm{mmol} \mathrm{NH}_{4} \mathrm{~m}^{-2} \mathrm{~d}^{-1}$ in aquaria without added nutrients) lie well within the range of those reported by Boynton \& Kemp (1985) and Nowicki \& Nixon (1985), but are somewhat lower than rates reported by Florek \& Rowe (1983). Boynton \& Kemp found that in Chesapeake Bay the ammonia release was highest in summer, max. $0.7 \mathrm{mmol} \mathrm{m}^{-2} \mathrm{~d}^{-1}$. Nowicki \& Nixon (1985) found that at $15^{\circ} \mathrm{C}$ (as in our experiment), less than $0.1 \mathrm{mmol} \mathrm{NH}_{4} \mathrm{~m}^{-2} \mathrm{~d}^{-1}$ was released during darkness and less than $0.05 \mathrm{mmol}$ $\mathrm{m}^{-2} \mathrm{~d}^{-1}$ during exposure to light in a shallow lagoon on Rhode Island, USA. This is comparable to the release rate at $5 \mu \mathrm{E} \mathrm{m} \mathrm{m}^{-2} \mathrm{~s}^{-1}$ obtained in our study.

Although the rate of denitrification in our experiment was not estimated, the low $N$ : P ratio ( 6 to 7 ) of the flux out of the sediment indicates general denitrification (see Blackburn \& Henriksen 1983).

It is difficult to distinguish the amount of nitrogen assimilated from the water by the benthic microflora from other $\mathrm{N}$-turnover processes in the sediment. In addition, the microflora assimilates $\mathrm{N}$ from the interstitial water. Although we did not analyse the interstitial water, the theoretical N-uptake by the microphytobenthos can be estimated using the amount of assimilated carbon and the $\mathrm{C}: \mathrm{N}$ ratio $10: 1$ for benthic microflora (Whitaker \& Richardson 1980, Hunter \& Russel-Hunter 1983, Brzezinski 1985). The calculated N-uptake (as $\mathrm{NO}_{3}$ ) for the period Day 5 to Day 29 in aquaria with added nutrients and exposed to $30 \mu \mathrm{E} \mathrm{m} \mathrm{m}^{-2} \mathrm{~s}^{-1}$ is 3.3 mmol $\mathrm{m}^{-2} \mathrm{~d}^{-1}$. The calculated value is equivalent to $106 \%$ of the measured decrease in the overlying water. In the calculations, the amount of assimilated carbon was corrected by a factor of 0.4 to allow for C-uptake measured in flasks where the algae received more light than they would in intact sediment (Cadée \& Hegeman 1974). If the Redfield ratio $(6.6: 1)$ is used, the $\mathrm{N}$ -

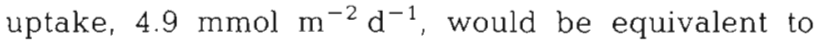


$158 \%$ of the $\mathrm{N}$-decrease in the overlying water, which indicates that a large part of the $N$ needed must be supplied from the interstitial water. Based on data from a 3 wk experiment, Granéli \& Sundbäck (1985) calculated that the benthic microalgae accounted for ca $20 \%$ of the disappearance of $\mathrm{N}$ from the overlying water and took up 40 to $60 \%$ of the total pool of nitrogen (interstitial water + overlying water).

Our results confirm the hypothesis that a correlation exists between light intensity, microphytobenthic activity and nutrient flux (Blackburn \& Henriksen 1979, Henriksen et al. 1980). The indirect influence of $\mathrm{mi}$ crophytobenthos on the flux, by changes in the $\mathrm{O}_{2}$ concentration at the sediment-water interface, was more important in our experiment than the direct uptake of nutrients by the algae. In light, oxygen production by photosynthesis prevented the release of $\mathrm{PO}_{4}$ and $\mathrm{NH}_{4}$ from the sediment. The effect of the microphytobenthic 'filter' depends on the amount and duration of the exposure to light. In our experiment, $10 \mu \mathrm{E} \mathrm{m}^{-2} \mathrm{~s}^{-1}$ (equivalent to $0.6 \mathrm{E} \mathrm{m}^{-2} \mathrm{~d}^{-1}$ ) was sufficient to maintain both an autotrophically dominated system and to prevent the outflux of $\mathrm{NH}_{4}$ and $\mathrm{PO}_{4}$. The stable chlorophyll a values during weeks of darkness indicate the survival of a potential 'filter effect' during temporary shading during the growing season.

Acknowledgements. Financial support was provided by the National Swedish Environmental Protection Board (grants to Kristina Sundbäck and Wilhelm Granéli), the Swedish Natural Science Research Council (grant to Wilhelm Granéli) and the Royal Physiographic Society of Lund (grant to Kristina Sundbäck). Dr Patricia Conway, Dept of Marine Microbiology, University of Gothenburg, corrected the English.

\section{LITERATURE CITED}

Admiraal, W., Peletier, H., Brouwer, T (1984). The seasonal succession patterns of diatom species on an intertidal mudflat: an experimental analysis. Oikos $42: 30-40$

Aertebebjerg Nielsen, G., Bresta, A.-M. (1984). Guidelines for the measurements of phytoplankton primary production. BMB Publ. No. 1, 2nd edn, Chariottenlund

Andersen, T K., Jensen, M. H., Sörensen, J. (1984). Diurnal variation of nitrogen cycling in coastal, marine sediments. I. Denitrification. Mar. Biol. 83: 171-176

Asmus, R. (1986). Nutrient flux in short term enclosures of intertidal sand communities. Ophelia 26: 1-18

Baille, P. W. (1986). Oxygenation of intertidal estuarine sediments by benthic microalgal photosynthesis. Estuar. coast. Shelf Sci. 22: 143-159

Balzer, W., Grasshoff, K., Dieckmann, P., Haardt, H. Petersohn, U. (1983). Redox-turnover at the sediment/water interface studied in a large bell jar system. Oceanologica Acta 6: 337-344

Björk-Ramberg, S. (1984). Species composition and biomass of an epipelic algal community in a subarctic lake betore and during lake fertilization. Holarct. Ecol. 7: 195-201
Blackburn, T H., Henriksen, K. (1979). Regeneration of nutrients from sediments. Vand 4: 117-122. (Danish)

Blackburn, T H., Henriksen, K. (1983). Nitrogen cycling in different types of sediments from Danish waters. Limnol. Oceanogr. 28: 477-493

Boucher, D. (1977). Production primaire saissonière du microphytobenthos de sables envasés en Baie de Concarneau. In: Keegan, B. F., Cédigh, P. O., Boaden, P. J. (eds.) Biology of benthic organisms. Proceedings 11 th European Symposium on Marine Biology. Pergamon Press, Oxford, p. $85-92$

Boynton, W. R., Kemp, W. M. (1985). Nutrient regeneration and oxygen consumption by sediments along an estuarine salinity gradient. Mar Ecol. Prog. Ser. 23: 45-55

Brzezinski, M. A. (1985). The Si: C:N ratio of marine diatoms: interspecific variability and the effect of some environmental variables. J. Phycol. 21: 347-357

Cadée, G. C. (1984). Has input of organic matter into the western part of the Dutch Wadden Sea increased during the last decades? Neth. Inst. Sea Res., Publ. Ser 10:71-82

Cadée, G. C., Hegeman, J. (1974). Primary production of the benthic microflora living on tidal flats in the Dutch Wadden Sea. Neth. J. Sea Res. 8: 250-291

Carlberg, S. (ed.) (1972). New Baltic manual with methods for sampling and analyses of physical, chemical and biological parameters. ICES Coop. Res. Rept. Ser A, Vol. 29

Chassé, C. (1983). Le potentiel de production des végétaux marins des côtes de France. Biomasse Actualités, N. S. 3 : $8-11$

Connor, M. S., Teal, J. M., Valiela, I. (1982). The effect of feeding by mud snails, Ilyanassa obsoleta (Say), on the structure and metabolism of a laboratory benthic algal community. J. exp. mar. Biol. Ecol. 65: 29-45

Enoksson, V. (1987). Nutrient recycling by coastal sediments. I. Effects of added algal material. In: Enoksson, $V$ Nitrogen flux between sediment and water and its regulatory factors in coastal areas. Doctoral thesis, University of Göteborg

Flint, R. W., Kamykowski, D. (1984). Benthic nutrient regeneration in South Texas coastal waters. Estuar coast. Shelf Sci. 18: 221-230

Florek, R. J., Rowe, G. T (1983). Oxygen consumption and dissolved inorganic nutrient production in marine coastal and shelf sediments of the middle Atlantic Bight. Int. Revue ges. Hydrobiol. 68: 73-112

Gargas, M., Gargas, E. (1982). Influence of temperature and oxygen conditions on phytomicrobenthos stored for longer periods in darkness. Vatten 38: 306-316

Granéli, W. (1984). The Laholm Bay project - presentation and preliminary results on sediment-water interactions in a eutrophicated shallow, marine area (SE Kattegat, Sweden). In: Henriksen, K. (ed.) 12th Nordic Symposium on Sediments. Rep. Botan. Inst., Univ. of Aarhus 8: 97-107

Granéli, E., Sundbäck, K. (1985). The response of planktonic and microbenthic algal assemblages to nutrient enrichment in shallow coastal waters, southwest Sweden. J. exp. mar. Biol. Ecol. 85: 253-268

Granéli, W., Sundbäck, K. (1986). Can microbenthic photosynthesis influence below-halocline oxygen conditions in the Kattegat? Ophelia 26: 195-206

Hansson, L.-A. (in press). Effects of competitive interactions on the biomass development of planktonic and periphytic algae in lakes. Limnol. Oceanogr.

Hellebust, J. A., Lewin, J. (1977). Heterotrophic nutrition. In: Werner, D. (ed.) The biology of diatoms. Blackwell, Oxford, p. 169-197

Henriksen, K., Hansen, J. I., Blackburn, T H. (1980). The 
influence of benthic infauna on exchange rates of inorganic nitrogen between sediment and water. Ophelia, Suppl. 1: 249-256

Hunter, R. D., Russel-Hunter, W D. (1983). Bioenergetic and community changes in intertidal Aufwuchs grazed by Littorina littorea. Ecology 64: 761-769

Kelderman, P. (1984). Nutrient concentrations in the intrestitial water of Lake Grevelingen sediment: effects of sediment redistribution and benthic primary production processes. Neth. J. Sea Res. 18: 312-336

Kennett, D. M., Hargraves, P. E. (1985). Benthic diatoms and sulfide fluctuations: upper basin of Pettaquamscutt River, Rhode Island. Estuar. coast. Shelf Sci. 21: 577-586

Kristensen, E., Blackburn, T H. (1987). The fate of organic carbon and nitrogen in experimental marine sediment systems: influence of bioturbation and anoxia. J. mar. Res. 45: $231-257$

Lorenzen, C. J. (1967). Determination of chlorophyll and pheopigments: spectrophotometric equations. Limnol. Oceanogr 12: 343-346

Nowicki, B. L., Nixon, S. W. (1985). Benthic nutrient remineralization in a coastal lagoon ecosystem. Estuaries 8: $182-190$

Nyman, U., Granéli, E. (1983). Alkaline phosphatase activity in the Laholm Bay, South-Eastern Kattegat. Sarsia 68: $275-279$

Plante-Cuny, M.-R. (1984). Le microphytobenthos et son rôle à l'échelon primaire dans le milieu marin. Oceanis 10 : $417-427$

Pringle, C. M., Bowers, J. A. (1984). An in situ substratum fertilization technique: diatom colonization on nutrientenriched, sand substrata. Can. J. Fish. Aquat. Sci. 41 : $1247-1251$
Raalte, C. D. van, Valiela, I., Teal, J. M. (1976). The effect of fertilization on the species composition of salt marsh diatoms. Wat. Res. 10: 1-4

Revsbech, N. P., Jörgensen, B. B. (1983). Photosynthesis of benthic microflora measured with high spatial resolution by the oxygen microprofile method: capabilities and limitations of the method. Limnol. Oceanogr 28: 749-756

Romagoux, J. C. (1976). Contribution à l'etude des populations microphytobenthiques du lac pavin (Puy de Dome). Thèse specialité, Clermont-Ferrand

Rowe, G. T., Clifford, C. H., Smith, K. L., Hamilton, P. L. (1975). Benthic nutrient regeneration and its coupling to primary production in coastal waters. Nature, Lond. 255: $217-219$

Sundbäck, K. (1986). What are the benthic microalgae doing on the bottom of Laholm Bay? Ophelia, Suppl 4: 273-286

Watanabe, Y., Tsunogai, S. (1984). Adsorption-desorption control of phosphate in anoxic sediment of a coastal sea, Funka Bay, Japan. Mar. Chem. 15: 71-83

Whitaker, T. M., Richardson, M. G. (1980). Morphology and chemical composition of a natural population of an iceassociated Antarctic diatom Navicula glaciei. J. Phycol. 16: 250-257

Wonnerberger, K., Höpner, T (1984). Experimentelle Untersuchungen zur Wirkung von Rohöl und Rohöl/TensidGemischen im Ökosystem Wattenmeer. VIII. Der Nährstoff-Efflux der Wattoberfläche: Ursache für die Patchiness der epibenthischen Primärproduktion und Bedingung für den biologischen Ölabbau. Senckenbergiana marit. 16: 105-119

Vries, I. de, Hopstaken, C. F. (1984). Nutrient cycling and ecosystem behaviour in a salt-water lake. Neth. J. Sea Res. 18: $221-245$

This article was submitted to the editor; it was accepted for printing on December 11, 1987 